in each of which its members have exceeded two thousand. The statistics for the quinquennium are shown in the accompanying table:

\begin{tabular}{lllc}
\multicolumn{3}{c}{ Meetings of the Association } \\
Year & Place & President & Membership \\
1931 & London & Gen. Smuts & 5702 \\
1932 & York & Sir Alfred Ewing & 2024 \\
1933 & Leicester & Sir F. G. Hopkins & 2268 \\
1934 & Aberdeen & Sir J. H. Jeans & 2938 \\
1935 & Norwich & Prof. W. W. Watts & 2321
\end{tabular}

It is a remarkable record and one that may well stimulate the Council to widen the already wide activities of the Association, and it is no secret that the Council has in consideration the possibility of a considerable increase in the Association's work. Regular research at Down House and the initiation of quinquennial reports on the progress of science-reports which shall elucidate to the non-specialist recent developments in scientific knowledge-are two instances out of many possibilities.
But increasing activities mean increased liabilities, and such liabilities emphasise the necessity for increased endowments. In the quinquennium under review, the Association has received legacies of $£ 2,000$ from Sir Charles Parsons, $£ 500$ from Sir Alfred Ewing, $£ 1,000$ from Mr. Bernard Hobson, and a gift of $£ 1,000$ from the local Committee for the Leicester meeting. On the other hand, the Centenary Fund appeal, coming as it did at a time of financial stress, failed in its object, and the gift of $£ 10,000$, made in 1926 by Sir Alfred Yarrow, was made under the condition that it should be completely expended not later than 1947. The remark of Sir Josiah Stamp that "further endowment will be essential to consolidate the position which the Association has attained at the end of its first century" is very pertinent.

The Association is to be congratulated on the production of an interesting and valuable survey of the work of five very full years.

\title{
Obituary
}

\section{Prof. J. Stoklasa}

$\mathrm{W}$ ITH the death in Prague on April 4 of Prof. Julius Stoklasa, agricultural chemistry has been deprived of one of its most active and distinguished exponents. Born on September 9, 1857, at Leitomischl in Bohemia, Stoklasa early showed his interest in science, and when only eleven years old was appointed curator of the school natural history collection. At the early age of sixteen years he developed an interest in plant nutrition and carried out experiments on the water culture of plants ; the results he obtained were communicated to the famous plant physiologist Prof. J. Sachs, who replied at some length and encouraged the young worker to continue his experiments with the view of publishing them.

At about this time, Stoklasa commenced a study of the effect of sulphurous acid, hydrochloric acid and hydrofluoric acid on plants, which study proved to be a forerunner of the work published fifty years later under the title of "Beschädigung der Vegetation durch Rauchgase und Fabriksexhalationen". During the same period of his life, Stoklasa became interested in geology, and as a result of this he undertook a study of the weathering of rocks. Leaving school, he proceeded to the Agricultural Institute in Liebwerd, where his knowledge of inorganic chemistry, acquired at school, stood him in good stead and enabled him to take up the investigation of the quantity and quality of the salts valuable to plants which were carried away yearly by the River Elbe.

From Liebwerd, Stoklasa went to the Agricultural College in Vienna, where, working in the laboratory of Dr. Zeller, a son-in-law and a former assistant of
Liebig, he published several investigations on plant biochemistry. On becoming Privatdozent at the University of Vienna, he worked in the plant physiological institute of Prof. Wiesner. Leaving Vienna, he went to Leipzig to study under Pfeffer and Ostwald, and obtained his doctorate for a thesis on the physiological properties of the water-soluble compounds of phosphoric acid contained in superphosphates. Recognising the importance of bacteria in the soil, he proceeded to Paris to study bacteriology at the Pasteur Institute, and on his return to Vienna he began to study the assimilation of atmospheric nitrogen by bacteria and plants.

For the next few years, Stoklasa was engaged in investigating the influence of phosphates and basic slag and other artificial manures on plant life. Start. ing an experimental station for beet sugar production in Prague, he became director of the section dealing with the physiology and pathology of the sugar beet : this gave him ample scope for his talents, and he proceeded to undertake an intensive study of nitrogen fixing and of denitrifying bacteria, and published a monograph on the phosphorus cycle in the soil.

Stoklasa's studies on intra-molecular respiration and the isolation of zymase from plants and animal sources were of fundamental importance. A study of soil fertility led him to investigate the significance of soil respiration in cultivated areas, and in 1926 he published a book entitled "Biophysikalische und biochemische Durchforschung des Bodens". He made important contributions to our knowledge of the physiological significance of phosphorus, sulphur, selenium and other elements, and published lengthy papers on the importance of potassium to the sugar 
beet, and on the distribution of aluminium in Nature and its significance in the cultivation and metabolism of plants. In later years he studied the influence of iodine on the growth and development of plants and also the effect of radioactivity upon metabolic processes in plants and animals.

Stoklasa was professor at the Technical High School in Prague, director of the State agricultural experimental station and vice-president of the Czechoslovak Academy of Agriculture.

\section{Prof. Georg Wiegner}

IT is with great regret that we have to announce the death on April 14 of Prof. Georg Wiegner, of the Agricultural Institute, Eidgenössische Technische Hochschule, Zurich. He had for some time been suffering from gastric ulcers, and underwent an operation which appeared to be successful, but peritonitis set in and ended fatally.

Wiegner was born in Germany, and received his training under Zsigmondy in Göttingen, then went straight to Zurich as professor of agricultural chemistry. Here he remained all his life, excepting that during the War he was temporarily in Germany for military service, and was wounded at least once. It is an open secret that he had been invited to a much more important chair outside Switzerland, but he preferred to remain in Zurich where, he said, he had been cordially received as a young and unknown man, and had familiarised himself with the agricultural problems of the Swiss farmers and discovered ways in which he could help them.

As might be expected from his training, Wiegner turned early to the study of the colloidal properties of the soil. It was at that time widely supposed, as the result of investigations by Way and by van Bemellen, that base exchange and some at any rate of the colloidal properties were due to zeolites in the soil. Wiegner took advantage of the possibility of obtaining permutite and other zeolites in quantity to make detailed studies by the new methods on base exchange, its nature and relation to the colloidal properties of the zeolite and of the clay, especially dispersion and flocculation, and he was able to work out an electrical hypothesis which threw considerable light on the whole phenomena. In the end it was shown in his laboratory that clay did not behave like permutite, and his hypothesis enabled him to explain the differences.

In 1930 Wiegner was invited to England to lecture at certain of the agricultural institutions so that members of the staffs might have the advantage of hearing his views and discussing problems with him. His lectures were published in the Journal of the Society of Chemical Industry for 1932 and constitute an admirable summary of the more important properties of clay and of zeolites.

In addition to these colloid investigations, Wiegner found time to study animal nutrition, choosing practical problems such as the drying and ensiling of grass, a very important matter in Switzerland; the evaluation of feeding stuffs with special reference to starch equivalents and gains in weight; and other subjects of farming interest. This work had the same high quality that characterised his soil investigations.

It was, however, as a teacher that Wiegner was supreme. He would come into the laboratory, call his research students together and start discussing some new idea, either his own or one of theirs, or he would sketch out some new experiment, and he would expect everyone to join in as eagerly as himself. On Saturday afternoons he would take a number of his postgraduate students for an excursion during which long discussions took place, lasting sometimes six hours or more, much of it in a village inn over beer, bread and cheese. The subjects were not necessarily scientific, but might even be political, and as his students came from many different countries and felt themselves entirely free and unconstrained, the discussions were often extremely interesting.

At the Congresses and Commission meetings of the International Society of Soil Science, Wiegner was always an outstanding personality; his geniality and kindliness towards his colleagues and his students endeared him to all who knew him. He added lustre to the Technische Hochschule of Zurich and he will long remain in the memory of his friends.

E. J. RuSSELL.

WE regret to announce the recent death at the age of fifty-eight years of Dr. Ernest Lobstein, dean of the faculty of pharmacy and professor of materia medica at Strasbourg, member of the Paris Academy of Medicine, and author of studies on the biology of the tubercle bacillus and chemical analysis of the mineral waters of Alsace, Bulgaria and Palestine.

WE regret to announce the following deaths :

Dr. William Bradley Coley, formerly professor of clinical surgery at Cornell University Medical College, New York, well known for his treatment of sarcoma by means of erysipelas and prodigiosus toxins, aged seventy-four years.

Prof. L. Frédericq, emeritus professor of physiology in the University of Liège, aged eighty-five years.

Dr. Alfred Palmer, one of the founders, and from 1926 until 1930 president of the Council, of the University of Reading, on May 20, aged eighty-three years.

Sir Robert Rait, C.B.E., principal and vicechancellor of the University of Glasgow since 1929 , on May 25, aged sixty-two years.

Mr. Arthur J. Weed, known for his work on seismology in the University of Virginia, on April 15, aged seventy-five years.

Errata. Obituary of Prof. Karl Pearson (May 23, p. 857): Mr. Udny Yule informs us that the dates of Prof. Pearson's books should read as follows : "Grammar of Science", 1892; "Chances of Death, etc.", 1897 ; "Ethic of Free-thought", 1888. 